\title{
Identity under Siege: Selective Securitization of History in Putin's Russia
}

\author{
Accepted manuscript version
}

Published version available as Bækken, Håvard, and Johannes Due Enstad. "Identity under Siege: Selective Securitization of History in Putin's Russia." The Slavonic and East European Review 98, no. 2 (2020): 321-44. doi:10.5699/slaveasteurorev2.98.2.0321.

\section{Summary}

This article explores state efforts to safeguard national history and identity in Putin's Russia. It is argued that a process of selective securitization has been taking place, whereby elite actors have defined certain (but not all) aspects of Russia's history and identity as vital and existentially threatened interests that need to be forcefully defended. This has paved the way for wide reaching state policy on the Great Patriotic War and given security actors an important role in its formulation. While the narrative of victory and unity surrounding the Great Patriotic War has become subject to securitization, state policy on the more contentious issue of Stalin's dictatorship has been much more ambiguous. When it comes to Stalin, the state has not sought to unify the population behind a common narrative, but rather to accommodate the value pluralism present among Russian elites and in society at large.

\section{Biographical note}

Håvard Bækken is a Senior Fellow at the Norwegian Institute for Defence Studies.

Johannes Due Enstad is a Postdoctoral Researcher at the Department of Literature, Area Studies, and European Languages, University of Oslo. 
In May 2016, a few hundred teachers and education officials took part in a conference hosted by the Moscow regional parliament. The theme was 'history teaching as a national security issue', and the conference was part of a larger cycle of events devoted to the patriotic education of the young -- how to make people love and be proud of their country and its history. The main speaker, a professor of history at one of Moscow's universities, painted a picture of Russia as being the target of a U.S.-directed information war with the ultimate aim of breaking up and destroying the Russian Federation. His core message was that the current official Russian ban on state ideology makes it impossible to use history as a defensive weapon in this information war. Not being able to defend Russian historical science against the enemy onslaught would lead to the disintegration of historical consciousness and, ultimately, 'the death of Russia'.

A similar sense of drama characterizes an article published on the website of the Russian Institute for Strategic Studies, a think-tank close to the Kremlin, entitled Threats to Russia's Cultural Security in the Context of Teaching in Schools. ${ }^{2}$ The authors warn against 'liberal ideology' in history textbooks, which subverts patriotism by highlighting the dark pages in Russian history. They conclude with a stark warning:

If the current state of history teaching in schools continues, Russia will run the risk, in the next 10-15 years, of losing her sovereignty and being split up into several dozens or hundreds of territories that will inevitably fight each other. This is the end goal of the internal as well as the external enemies of the Russian Federation. ${ }^{3}$

These statements vividly illustrate the main argument of this article: In Putin's Russia, elite actors have subjected history in particular -- and national identity in general -- to a process of securitization.

Securitization occurs when state and other influential actors ('securitizing actors') define some issue as a vital interest under existential threat, implying that someone must take forceful action in its defence. Our argument, that Russian elites have set out to securitize Russian history and identity, complements that of Jardar Østbø, who perceptively analyses the 'moral turn' under Putin, arguing that the ongoing 'securitization of spiritual-moral values' has become a way for the regime to 'create and 
bolster the perception that the Russian state is existentially threatened', in order to keep the population in 'survival mode'. ${ }^{4}$ To securitize an issue means to bring it under political control -- to remove it from 'the realm of ordinary public deliberation, discussion and debate'. ${ }^{5}$ In this, it deviates from politicization, as also underscored by Buzan, Wæver, and de Wilde (the creators of the securitization framework). ${ }^{6}$ Indeed, politicization and securitization may in certain contexts signify opposite phenomena, particularly in open liberal democracies. In the case of the authoritarian and security-dominated political environment of Russia, however, one could see the two terms as more closely related.

We also argue that the securitization of history in Putin's Russia has been selective: not all important historical topics have been getting the security treatment. While the state clearly seeks to control the Great Patriotic War narrative of unity and victory, other politically salient topics have escaped a full-fledged securitization. Our case in point is the issue of Stalin's dictatorship, on which policy has been fluctuating and indecisive. When it comes to this contentious and divisive topic, Putin's history policy has not sought to enforce the 'party line', but rather to accommodate the value pluralism and differing interpretations prevalent among Russian elites. ${ }^{7}$

The article proceeds as follows. After a brief clarification of the securitization concept, we review domestic and international contextual factors that gave rise to the securitization of history and identity well before the 'morality turn' of 2012 and the subsequent sharpened conflict with Western powers since $2014 .^{8}$ Second, we move on to examine how Russian authorities have securitized history and identity, particularly with respect to post-2012 speeches and security doctrines. We then show how the state has moved to safeguard the official narrative of the Great Patriotic War. Finally, we review policies and statements that have contradicted the official line of patriotic history policy, particularly with regard to Stalinism. We interpret these deviations as pragmatic concessions to alternative visions of Russian history and identity, corresponding to competing (or complementing) political agendas -liberal, neo-Stalinist, and Orthodox. 


\section{The Securitization of National Identity}

The examples provided in the introduction illustrate how Russia is going through a process of identity securitization. ${ }^{9}$ For its tendency to legitimize its style of government by reference to vital security threats, contemporary Russia makes a strong case for applying securitization perspectives on a number of policy themes. ${ }^{10}$ State efforts to safeguard identity and history have gained momentum throughout the Putin period. Identifying the beginning of this tendency to a single event or year would be artificial; our study instead identifies a subtle development going all the way back to the development of the first state programs of patriotic education in the late 1990s. New since that time is not the existence of securitizing agents, who have been present all along, but their increasing political prominence and impact.

Russia's identity securitizers are not simply identifying a fundamental threat to Russian identity and historical consciousness. Often, they also claim that Russia's enemies have already done much harm. Following this, efforts to secure current identity is often coupled with reactionary attempts to roll back harmful influence and restore a purported 'natural' identity. Securitization represents a search for a stable identity, regardless of its existence in the first place. ${ }^{11}$

Importantly, the securitization of identity opens the door for emergency measures to save, or restore, it: Large-scale identity programs, far-fetched narratives in history textbooks, legislating history laws, and the involvement of military and security agencies in policymaking and implementation. ${ }^{12}$ As will be illustrated in the following, securitizing a policy area not only provides an impulse for additional state attention, but also helps manoeuvre decision making into the hands of security experts. In line with Wilhelmsen, we contend that 'securitizing moves' do not lead directly to emergency measures in a linear fashion, but merely reproduce and strengthen a securitizing discourse already present. This securitizing discourse, moreover, does not cause radical state measures, but changes the conditions under which policy decisions are made. Securitization makes radical measures seem possible and legitimate for a relevant audience. ${ }^{13}$ 


\section{The Context of Securitization: Domestic Moral Crisis and Foreign Rival Narratives}

State efforts to securitize national identity and history are nothing new in Russia. $19^{\text {th }}$ century tsars defended the doctrine of 'Orthodoxy, Autocracy, and Nationality' in order to safeguard a particular conception of Russian identity; Khrushchev warned that historians were 'dangerous people' who had to be 'directed'; ${ }^{14}$ other Soviet leaders considered even western pop music and jeans as threats to national sovereignty. The breakup of the USSR created a new dynamic around the question of identity and security, a development propelled by two main factors. First, the economic, ideological and moral disintegration of Russia in the early 1990s led to widespread elite concerns about the future of the Russian nation. Such concerns prompted increased political attention to national history and resurrected the old tsarist idea of official Russian patriotism. Second, the collapse of the Soviet order brought about a wave of nation-building and active state policies of history in other post-Communist countries. Because these new national narratives were largely in conflict with their Russian equivalent, and therefore perceived as a threat, they had a significant impact upon Russian policies. In the following, we deal with these two topics in order.

In the first half of the 1990s, not only the Soviet state, but also its ideology and historical myths crumbled. The years of 1990 and 1991 were marked by 'outspoken and unqualified condemnations' of the Soviet past, attacking the core myths of Soviet history. ${ }^{15}$ While some historians stubbornly stuck to the old narratives, the Soviet collapse and the opening of Soviet archives paved the way for an unprecedented and public historical examination of what had earlier been taboos -- the dark sides of Soviet rule. The outpouring of critical perspectives on the Soviet past led to a conservative reaction which still characterizes official patriotic discourse, with talk of combating 'historical masochism' and counteracting attempts by Russia's enemies to 'falsify' and 'deheroize' its history. ${ }^{16}$

'When the 'bomb of westernism' exploded in Russia', wrote Aleksandr Zinoviev, 'it hollowed out not only the governmental, economic, ideological and cultural spheres, but also the very human material of society. ${ }^{17}$ As a result of the prolonged crisis associated with the liberalization and privatization of Russia -- marked by corruption, political manipulation and rampant social problems -the common disillusion with Soviet ideology was soon followed by embitterment with western ideals. Understandably, the crisis also resulted in reduced sentiments of love and respect for the Russian nation 
and state, so fundamentally in disorder and without a functioning ideology to legitimize it. Problems were further exacerbated by political fragmentation and a humiliating military defeat in Chechnya. Domestic production of consumer products dropped, as did Russian productions for TV and cinema. ${ }^{18}$ Often, moral degradation and a sense of lost dignity were linked to foreign influence. As a writer lamented: 'The social values of the Santa Barbara 'heroes' are more important for us than our own national values and passions. ${ }^{19}$ 'The process of national degradation', warned a Russian sociologist, 'is already a real danger sounding the alarms of the whole society. ${ }^{20}$

While the Yeltsin camp certainly distanced itself from the Soviet past, and consistently worked to undermine the political impact of the Communist Party, Yeltsin himself was reportedly 'quite alien' to the idea of using history as a political instrument. ${ }^{21}$ The liberals found it difficult to engage in a fullfledged history policy along anti-Soviet lines, since any active identity policy would be associated with the regime they despised. ${ }^{22}$ Following the liberals' defeat in the 1995 Duma elections, however, the Yeltsin government realized that an ideological shift was necessary. Although the liberal agenda was by no means abandoned, it was increasingly mixed with traditional patriotic ideas. In the second half of the 1990s, Yeltsin set down a commission to ponder on 'the Russian idea', reintroduced military parades on Victory Day and made moves towards the political centre to avoid excessive polarization. ${ }^{23}$ In his last term as president, Yeltsin supported an initiative from the Ministry of Defence to formulate a traditionalist policy concept of patriotic education. ${ }^{24}$ At the same time, private enterprises increasingly realized the commercial prospects of the patriotic brand.$^{25}$ The following years, patriotic history writing became increasingly important to the authorities to induce national pride among the population. As international tensions grew under Putin, securitizing approaches gradually became more salient. Securitizing statements became more frequent at higher levels of politics, and eventually came to influence state policy, as we shall see.

Putin's turn to a more assertive history policy and further promotion of Russian patriotism must be understood in the context of the perceived de-ideologization and moral crisis of the 1990s. Consider Putin's address to the Federation Council in 2012: The dismantling of Soviet ideology was necessary, he admitted, but in the process, Russia lost a part of itself: 'We ended up throwing out the baby with the 
bath water. ${ }^{26}$ To save the country from imminent collapse and make Russia great again, national selfrespect had to be kick-started, an idea central to official identity discourse under Putin.

Russia was not the only country that started intensifying official policies of history in the first decade of the 2000s. On the contrary, Russia was part of a wave of renewed interest of post-communist states in their national histories. The narratives of other countries, however, often conflicted with the Russian. Indeed, the elites of many newborn regimes framed Russia and the Soviet Union as the main antagonists in their national history writing. The victim narrative has been central to many countries formerly under Soviet influence -- the past is presented as suffering under 'the evil intentions of foreigners'. ${ }^{27}$ Ukrainian history textbooks, for instance, have been described as emphasizing Russian 'violence, cruel policies and destruction'. ${ }^{28}$ Particularly in the cases of Poland, Ukraine and the Baltic countries, conflictive historical narratives affected Russian policymaking under Putin and Medvedev. Tendencies in these countries to equate Nazi and Soviet occupation, for instance, played directly into Russia's establishment of a special history commission 'to counteract attempts to falsify history to the detriment of Russia's interests' in 2009 and the introduction of a new article in the Criminal Code, initiatives we discuss below. ${ }^{29}$

While some state initiatives were implemented in post-communist countries already in the early 1990s, the policies often reached their climax only later, coinciding with renewed Russian attention to historical narratives. They also took many of the same forms as Russian policies did: patriotic programs, erection or demolition of monuments, writing new history textbooks, establishing institutes of national remembrance, creating of museums under political patronage and passing history laws. ${ }^{30}$

Because the historical narratives were often discordant, the increasingly active policies of history in these and other states led to what became known as the 'history wars' of post-communist Europe. Russia several times clashed with Poland over the memory of the massacre in the Katyn forest in 1940, and the relationship between Ukraine and Russia was rife with historical disputes well before the escalation of conflict in 2014, not least with regard to the famines under Stalin and the role of the Banderite movement in the Second World War. Quarrels over Estonia's monument landscape culminated in 2007 with the removal of a Stalin-era bronze soldier from central Tallinn, unleashing riots and repeated cyberattacks against Estonian state institutions. The examples are not unique. 
In a setting where both parties see their narratives as sacred, quarrels about purported historical truths are doomed to become a dialogue of the deaf. As pointed out by the Estonian researcher Maria Mälksoo, these confrontations between neighbouring states show how securitization of historical memory by no means increases the feeling of security in the countries in question. Instead, the 'history wars' replicate the classical security dilemma on the arena of national identity: Because the securitized national narratives often are in mismatch with each other, one state's identity security is seen as detrimental to the identity security of others. This again leaves all participants in the game of security fundamentally insecure and mobilized for a continued battle of historical narratives. In this way, the securitization of historical memory 'tends to reproduce insecurities and reinstate historical animosities instead of alleviating them'. ${ }^{31}$

\section{An Official Discourse of History and Identity under Siege}

A mentality of identity siege is salient at the highest level of government. Upon becoming president, Putin immediately made it clear that he wanted to restore national pride by using Russian history. At this point in time, national history should not be considered securitized. Yet, the still limited discourse of patriotic education contained strong elements of alarmism, not least among military officials. ${ }^{32}$ Following the above-mentioned 'history wars', officially voiced concerns about hostile forces plotting to destroy Russian historical consciousness, national character and cultural sovereignty became more common. ${ }^{33}$ Alarmism in identity and security issues became a prominent feature in the 2012 'morality turn' in official discourse, and identity security and the fight against historical falsification are today included in official doctrines. In the words of the Russian philosopher Alexander Rubtsov, 'life is becoming more and more ideological, while ideology is becoming more historical'. ${ }^{34}$ The development of today's approach has been gradual, from employing patriotic history writing as a political tool from the late 1990s, to an increasingly securitizing approach since about 2007 and even more so since the beginning of Putin's third presidential term in 2012.

2012 was a notable year in Putin's own adoption of a securitized identity discourse. In his address to the Federal Assembly that year, Putin stated: 'If the nation is unable to preserve and reproduce itself, if it loses vital references and ideals, it does not need an external enemy because it will fall apart 
on its own. ${ }^{35}$ The statement signalled that Russian national identity is not only a matter of moral or cultural security -- Russians losing themselves and turning into something they are not. It is also a matter of security in the traditional sense: National identity secures the integrity of state territory. If the nation disintegrates, so does the state. In another 2012 speech, Putin warned that 'the distortion of national, historical and moral consciousness has led to catastrophe for entire states, to their weakness and ultimate demise, the loss of sovereignty and fratricidal wars'. ${ }^{36}$ In his 2013 Unity Day speech, the warning was even more direct: '[We must] realize how great an abyss of ruin and loss we face if we neglect national interests and forget our moral foundations and unique identity, ${ }^{37}$ Key state bodies have followed up on Putin's alarmism. In a 2016 Presidential Security Council meeting, participants reportedly discussed how historical memory has become an object of 'targeted destructive acts from foreign state institutions and international organizations to fulfil geopolitical interests in line with antiRussian policies' ${ }^{38}$

The actors cited above invoke a sense of urgency by reference to the current tensions and alarmist visions of the near future. Urgency, of course, is permanent, since identity by definition is fluid and changing. ${ }^{39}$ For purposes of nation building, however, the Russian national character is presented as a semi-permanent feature distinguishing the Russian civilization from the rest. This representation is key for mobilizing support for the securitization of identity. Yet, 'since identities are always in the making $[\ldots]$ the promise of stability in securitization practices is illusory'. ${ }^{40}$

The degree to which history and identity security has become an integrated part of state policy is visible in the mark it leaves on key state security documents. In the 2015 National Security Strategy, for instance, several passages mention ideological threats, such as threats against the 'cultural sovereignty' of Russia, foreign countries 'falsifying history', and the 'erosion of traditional Russian spiritual and moral values [...] by means of external cultural and information expansion' ${ }^{41}$ The 2014 Military Doctrine listed the undermining of 'historical, spiritual and patriotic traditions related to the defence of the Motherland' under the heading "main internal military dangers". ${ }^{4}$ 


\section{Enforcing the Memory of the War}

Central to the securitization of history and identity is the Great Patriotic War, which through extensive commemorative and nation-building practices has arguably transformed 'into a master narrative of the Russian national identity'. ${ }^{43}$ Even explicitly civilian (grazhdanskii) patriotism is permeated by this theme. ${ }^{44}$ Notably, the Great Patriotic War is not identical to the Second World War, but refers to the Russian war against Nazi Germany in the years 1941-1945. The Soviet tradition of focusing on the Great Patriotic War tends to downplay the much more contentious Molotov-Ribbentrop pact of 1939, the subsequent Soviet invasions and annexations, the large-scale repressions against real and imagined enemies in the annexed/occupied territories, and the contribution of Russia's allies to the victory. ${ }^{45}$

The epic story of the War transcends ethnic and religious divisions, glorifying both state and nation. It was for these unifying qualities it was exploited in full by Soviet propaganda since the 1960s, and still is today. As President Putin himself has noted: the memory of the victory makes 'all, all disagreements -- ideological and generational' disappear and 'unites and reconciles everyone in Russia'. ${ }^{46}$ The War serves as a positive focal point to anesthetize the nation against its bad memories -the ambiguities and troublesome aspects of Russian history where the people all too often has fallen victim to the state itself.

Given the huge scale and impact of the Second World War for both Russian and world history, a certain priority granted to the war years is of course only to be expected. Hyperbolic representations of national heroism are also commonplace in popular accounts of military history elsewhere. As Ernest Renan puts it, 'getting history wrong is part of being a nation' ${ }^{47}$ Critical observers, however, have criticized both the ritual content and the scale of the Russian commemoration, described as a state-driven 'cult' and a 'national obsession' taking mythical proportions. ${ }^{48}$ In the words of Alexei Miller, 'by taking advantage of the administrative and financial resources of the state, the dominant political forces carry out the ideological indoctrination of society in the realm of historical consciousness and collective memory'. ${ }^{49}$ The ability to bring about this change was strengthened by the gradual securitization of history and national identity: On the pretext of countering alleged threats against the Russian nation, the political leadership displayed an increasing willingness to employ heavy-handed tools to promote its identity templates and preferred narratives on selected topics. In the field of military history, this has 
been particularly evident. In the following, we will examine the policy of patriotic education, before looking at even more direct means of upholding state narratives of the war.

\section{Patriotic Education: Russia's Official Love Potion}

Under the banner of patriotism, Putin regime has been trying to rally the multi-ethnic population behind a common national idea, a certain set of values and support of the Russian state. Appearing as an important ideological focal point for identity discourse already in the mid-1990s, the patriotic brand has been actively harnessed by state authorities. To circumvent political opponents mobilizing nationalist sentiment against the regime, the political leadership has rather successfully attempted to take control over the 'strategical tag' of patriotism, using it for its own purposes. ${ }^{50}$ The patriotic centrism of Putin's regime is, in other words, driven by a mix of consensus-seeking and top-down initiatives. Since the Crimea annexation, official patriotism has arguably come as close to a state ideology as it could without violating the constitutional ban. In 2016, Putin declared in a strikingly authoritative manner that Russia's unifying ideas was patriotism, and that it could be no other. ${ }^{51}$

The main programmatic drive of official patriotism is the State Program of Patriotic Education of Russian Citizens (State Program), whose main features are the official Concept of Patriotic Education and regular five-year plans with both policy content and financial set-up for specific projects. ${ }^{52}$ The first five-year plan commenced in 2001; the fourth and current runs from 2016 to 2020 . The sources of patriotism envisioned in the State Program are highly traditional -- almost exclusively centred on the military and military history of Russia. Among the concrete projects supported by the five-year plans, a great many publications, conferences, exhibitions, competitions and festive events commemorate past military achievements. The Great Patriotic War consistently gets the lion's share of attention. The programmatic texts also serve as a foundation for other plans and activities conducted around the country, including both regional plans and various local initiatives. ${ }^{53}$

By means of military glory of the past and present, Russia is supposed to tackle a whole range of threats against the state and nation. The sense of sustained crisis has manifested in aims to restore Russian spirituality and secure and stabilize the country. Only with the most recent five-year plan, the 
picture of a Russia in distress is finally fading into the background. The emphasis on military traditions and history, however, remains and even expands.

Importantly, the policy makers also intend to counter radical ethno-nationalism and build friendship among the various ethnic groups of Russia, so crucial for the Russian federative model. In practice, however, the multi-ethnic character of Russian patriotism has been challenged. One study, for instance, documented how Tatar organizations used "patriotic state funds" to promote distinctly ethnonational perspectives. ${ }^{54}$ Purported multi-confessionality is also at risk, with the Russian Orthodox Church taking a dominant role in a great many of the activities. ${ }^{55}$ According to J. Paul Goode's research, the opaque character of patriotism frequently leads to a relapse into ethnic characteristics when Russians are asked to elaborate on its meaning. To a considerable extent, Good argues, Russian patriotism is "patriotic in form, but nationalist in content". ${ }^{56}$ Yet to a certain extent, the need to transcend ethnic and religious identities can explain the elevated position of the military and military history in Russian history policy.

While Russia's official basis for patriotism has deservingly been criticized for overly vague language, some general aims are set down. First, the programmatic texts explicitly frame the inducement of traditional patriotism as a matter of military prestige and defence capabilities. Echoing Soviet experiences, the ideological indoctrination is practiced side by side with military training. The logic of ideological training in this context is that real Russian patriots would love to join the armed forces and sacrifice themselves defending the Fatherland. In more practical terms, the Russian Armed forces hope to get better and more recruits, both conscripts and soldiers on contract. ${ }^{57}$ The scholarly attention to patriotic education has tended to highlight this feature of the program, arguably at the expense of its ideological purposes. ${ }^{58}$ A second important goal of patriotic education is the moral revival and 'spiritual rebirth' of Russians; the rediscovery of traditional Russian values. As the argument goes, the post-Soviet generation 'lacks the moral fibre required of future heroes'. ${ }^{59}$ The need for spiritual rebirth is given strong emphasis in policy documents and has been very prominent in the patriotic discourse, where a number of policy actors have voiced variants of the reactionary moral cliché. In the early debates leading up to the program of patriotic education, the emphasis on 'moral security' was particularly strong. ${ }^{60}$ In this context, a sting towards stereotyped western values was common: Russia had lost its 'true self' to 
the influx of alien ideas from the West. The official Concept of Patriotic Education captures this sentiment, and sees patriotic education as a remedy against widespread 'indifference, egoism, individualism, cynicism, unmotivated aggression, disrespectful attitudes to the state and social institutions'. The Concept of Patriotic Education notably declares that the policy should aim to 'establish conditions for the national rebirth of Russia as a great power', a formulation for some reason absent in other texts. It expects from Russian patriots great sacrifice "to the point of death", but offers little in return save for positive feelings of duty and pride.$^{61}$ In short, the State Program is extremely ambitious but has rather few means to its disposal beyond stories and narratives.

The heavy load put upon the two shoulders of past and present military glory helps explain the strong state involvement in the subject of history. It feeds on securitizing discourse, situating patriotism at the centre of the value universe, identifying threats and calling for wide-reaching measures. Not only do the plans call for the coordinated efforts of all state institutions on all levels, including not least the educational system. In addition, civil society has its part to play, and the use of mass media is central to the strategy. A range of talk shows, war movies and documentaries have explicit goals of building patriotism. The Ministry of Defence has its own TV-channel, Zvezda, exclusively dedicated to patriotic content, usually meaning Soviet cinema classics, musical events, cartoons and occasional documentaries. ${ }^{62}$ On the margins of the State Program, militaristic initiatives have mushroomed. Wellknown initiatives like the Iunarmia Youth Organization and the Park Patriot outside Moscow are but the most visible manifestations of a more comprehensive tendency. As in the State Program itself, the activities are frequently structured around popularized military history and celebrations.

Indicative of a process of securitization, military actors have been directly involved in patriotic education policy development and implementation. ${ }^{63}$ The initiative to make a patriotic education a state priority belongs with the Russian military establishment, who since 1992 has had a special department for this form of indoctrination. Clearly, they have not simply been responding to a threat, but have themselves been participating in securitizing history and identity. ${ }^{64}$ Today, a whole range of state institutions contributes as partners to the project, including security actors such as the Federal Security Service (FSB) and the Ministry of Defence, but no academic institutions. Until 2016, a state organ for 
nurturing civilian-military relationships was coordinating and leading the implementation of the fiveyear plans. ${ }^{65}$

\section{Fighting Historical Falsifications}

Following the 'history wars', the Russian state has displayed increasing willingness to enforce its interpretation of historical events, primarily connected to the Great Patriotic War. In 2009, then President Dmitri Medvedev established a special Presidential Commission of the Russian Federation to Counter Attempts to Falsify History to the Detriment of Russia's Interest (the Falsification Commission). It was formed in order to monitor attempts to revise the historical truth of the Second World War in an anti-Russian direction and to advice the President on how to counter them. The Commission chair, Sergei Naryshkin, envisioned it as an 'organizational base to ensure the protection of our own history from dishonest attempts to distort it ${ }^{66}$ Tellingly, among the twenty-eight members, there were several employees from the power ministries, the Armed Forces and the Secret Services, but few independent historians. ${ }^{67}$

While the commission was dissolved before it had achieved much, the initiative to battle antiRussian historical narratives lives on. While the Falsification Commission ceased to exist, the old tsarist institutions of Russian Historical Society (RIO) and the Russian Military-Historical Society (RVIO) were reborn only months later. RIO has a far broader mandate than the Falsification Commission, includes a wider range of partners, and is allegedly dedicated to an 'objective and impartial study of historical events' ${ }^{68}$ At the same time, RIO inherited from the commission the role of a state-led historical arbiter, taking on the responsibility to fight 'dilettantism and attempts of falsification' ${ }^{69}$ It also inherited the commission's leader, Sergei Naryshkin, who now had freed up time on his schedule. The suppression of so-called historical falsifications also remains part of the patriotic education program, as well as other key documents such as the National Security Strategy and Concept of Foreign Policy. ${ }^{70}$ Reportedly, there is even a special task force within the Russian military where conscript-historians fight falsifications of the Second World War. ${ }^{71}$

Another important event in the efforts to protect the official narrative by institutional means was a breakthrough in the lengthy attempts to pass a law to secure the 'historical truths' of the Great Patriotic 
War. In 2014, the article 354.1 in the Criminal Code of the Russian Federation was born, which made it a criminal offense to rehabilitate Nazism and, more vaguely, to 'spread information on military and memorial commemorative dates related to Russia's defence that is clearly disrespectful of society and to publicly desecrate symbols of Russia's military glory'. The article allows for considerable punishment; penalties up to 300,000 robles or equivalents of two years of salary, and up to three years' incarceration. While some welcomed a more active stance against Holocaust deniers, the other phrases of the law provoked criticism. ${ }^{72}$ It was arguably overstepping an important line of state involvement in history, using legal measures to protect the state's heroic narrative about itself. In the words of Mälksoo: 'Setting legal frames on how 'our story' can be remembered is, in a sense, the ultimate securitization, because it 'ontologizes' a particular story, making it an unchanging part of the state's self-definition. ${ }^{.73}$ Ultimately, the state puts to use its most powerful weapon, its theoretical monopoly on legitimate violence, to enforce its historical narrative. Because access to state channels in Russia is skewed and personal, however, the law also provoked fears of selective law enforcement, a reoccurring issue when it comes to anti-extremism and hate crime legislation. ${ }^{74}$

In 2016, a Russian citizen was found guilty under the mentioned article for displaying 'profanities and expressions of negative attitude towards the St. George ribbon as a symbol of the Russian military glory ${ }^{71}$. A few months later, another citizen was sentenced to a 200,000 rouble fine for reposting on social media what the SOVA institute finds to be 'a free understanding of the MolotovRibbentrop Pact as well as a number of questionable statements relating to the Bandera movement' ${ }^{70}$. Among other strange moments that took place in the courtroom, the accused was confronted with his good marks in history class as evidence he should have known the article contained erroneous historical claims. $^{75}$

Several publicized episodes of what seemed like extra-legal enforcement of historical narratives also took place in Putin's third term. In 2014, Andrei Zubov was fired from his job at the University of International Relations in Moscow, seemingly due to an article published in Vedomosti, where he drew parallels between the Crimea annexation and Nazi Germany's Anschluss of Austria. ${ }^{76}$ Whether the episode can be attributed to state policy remains an open question. The next year, Sergei Mironenko, the director of the Russian State Archive, was reassigned (or relegated) following a quarrel with the minister 
of culture, Vladimir Medinskii. Mironenko had been claiming that the Soviet story of the heroic Panfilovtsy was an historical myth and deliberate falsification by Soviet propaganda, and pointed to a previously classified document to support his claims. ${ }^{77}$ The minister's involvement in the then soon-to-

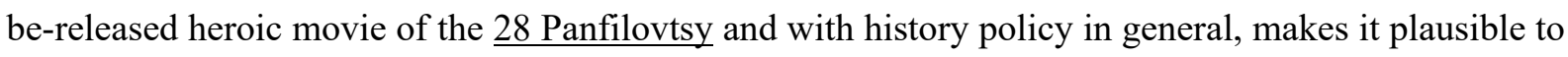
interpret the relegation as political signal. ${ }^{78}$ Both parties, however, denied any connection between this quarrel and Mironenko's reassignment. ${ }^{79}$ Other controversial cases from recent years include the stripping of historian Kirill Aleksandrov's doctoral degree (on the anti-Soviet Vlasov movement in World War II) and the persecution of historian and local Memorial leader Yurii Dmitriev, apparently for his investigations into Stalinist terror. ${ }^{80}$

\section{Pragmatism, Contradictions, and Concessions}

While the main line of Putinist policy on national history is evident, the regime's approach also contains important contradictions and concessions. Despite the paternalistic, idealizing and state-centred features of history policy, the Kremlin has also been trying to appease both liberals and conservatives. The irreconcilable ideological stands of liberals/westernizers and traditionalists, each with their own perceptions of 'historical justice', seem to be a semi-permanent feature of the Russian ideological landscape ${ }^{81}$ In cases where construing a consensus is too far-fetched, then, authorities have seemingly pursued a policy of pluralism. Especially in the case of the politically sensitive issue of Stalinism and Stalinist repressions, state policy has had obvious elements of pragmatic manoeuvring and balancing.

Several factors can explain policies that diverge from the assertive line reviewed above. Certainly, there is a temporal dimension: Establishment of an assertive main line in Putin's first terms, followed by more liberal tendencies under Medvedev in 2008-2012, and finally a return to the main line in the wake of the 2014 Crimea annexation. Alternatively, we can focus on contradictions in the pursued policies, observing how a given policy actor frequently fails to be consistent in its acts and statements. Internal contradictions can be found in Putin's speeches, in history textbooks or even in the patriotic education program. Finally, we can interpret the inconsistency in terms of concessions in order to satisfy

particular agendas and appease the groups advocating them, be it Stalinists or liberals. In order to account for the complexities of Russian history policy, all these perspectives should be integrated. 
Despite Medvedev's de facto subordination to his patron Putin, his presidency in 2008-2012 signalled a significant revision of the regime's policy of history. The infamous Falsification Commission was established at this time, the first draft of the 'history law' appeared, and Medvedev hardly influenced the patriotic education programs. Other events and statements in the period, however, gave observers hope that history would be given back to historians or at least treated in a more relaxed manner. Historian Alexei Miller ended a 2011 article on a positive note: 'Russia has escaped the outburst of historical policy that seemed inevitable in 2009. ${ }^{82}$ With Putin's return to presidency in 2012, however, such hopes were soon dispelled. The tightening of the screws in domestic politics in wake of the Crimea annexation, the Russian historian found, 'fully manifested themselves in memory politics'. ${ }^{83}$

In his review of Putin's history policy, Kristian Gjerde emphasizes the complexity and incoherence of the Kremlin narrative, and the ways in which the Kremlin has mediated widely differing positions in order to reach historical consensus. Gjerde claims that conventional analyses of Russia's history policy are 'skewed' and that the many contradictions are often overlooked. ${ }^{84}$ The infamous Filippov history textbooks provide the perfect illustration of internal inconsistencies, he states, as they borrow 'phrases and explanatory models from widely different and incompatible narratives and world views'. ${ }^{85}$

To be sure, the Russian policy of history seems both centrist and populist. Obviously, the policy makers have endorsed the Great Patriotic War not just because it was the best story for their purposes, but also because it resonated with the population. Although the Kremlin has paid concessions to both the liberal and the conservative camp, however, there has been little doubt as to the regime's role as the ultimate arbiter of state policy. At the same time, Gjerde is clearly right about the Kremlin not being an extreme party in the debate over history and identity. Indeed, the existence of more authoritarian or hardliner approaches is vividly illustrated by examples in the introduction to this paper, and elite actors have raised explicit calls for a full-fledged state ideology. The liberal and nationalist-patriotic oppositions have both been attacking the Kremlin for what they see as manipulative policies to legitimize its own regime. Whereas the liberals accuse President Putin of rehabilitating Stalin, the communists accuse him of demonizing the dictator. ${ }^{86}$ By means of its history policy, the Kremlin purposefully tries to navigate 
in this extremely polarized discursive landscape. The dependence upon the World War II mythology in history policy is not least due to the lack of alternative consensus-building topics.

If the Great Patriotic War has been the perfect topic to highlight and harness Russian national consensus, the related issue of Stalinism remains a bone of fierce contention. Nowhere is the navigation on the ideological oceans of Russia harder than on the issue of Stalinism, and the Russian history policy reflects this. In its attempts to deal with the differing interpretations of Stalinism, official Russia has pursued a give-and-take policy, rife with contradiction and concessions to several agendas.

Both elites and general public opinion are highly polarized with regard to the assessment of Stalin's role in Russian history. ${ }^{87}$ Sociologist Boris Dubin suggested that there are in fact two Stalins in Russian historical consciousness: 'Stalin the tyrant, and Stalin the victor in the Great Patriotic War'. ${ }^{88}$ According to Dubin, there is a fundamental rupture between the two Stalins: Both images are popular, and there is no middle ground. ${ }^{89}$ Putin has himself commented on the dual role of Stalin: 'Stalin was, of course, a dictator $[\ldots]$ the problem is that it was under his leadership the country was victorious in World War II, and this war is to a large extent connected with his name. ${ }^{90}$ Exactly for this reason, the Stalin question will remain a wellspring of dissonance in the official historical narrative for years to come.

Much attention has been paid to the alleged rehabilitation of Stalin, not least in the cultural sphere. ${ }^{91}$ For a large part, active elite groups at the margins of power have been steering the process, fuelled by popular demand. At the same time, the Kremlin has accepted the development, and even supported it on a regional level. ${ }^{92}$ Controversial acts with policy ramifications include the renaming of streets to the memory of Stalin, rehabilitation of a Stalin homage on the Moscow metro, and the replacement of the famous Perm' 36 Gulag-museum. The 2015 unveiling of a massive statue of the 'Big Three' (Stalin, Churchill and Roosevelt) in Yalta was attended by Naryskhin personally. ${ }^{93}$

Polls conducted by the Levada Center indicate a new surge in Stalin's popularity since the Crimea annexation. ${ }^{94}$ Ivan Kurilla suggests that the conflictive relations with the West and the Kremlin's concurrent flirt with Stalinism have combined to unleash an 'avalanche effect that threatened to escape the Kremlin's control'. ${ }^{95}$ Indeed, the Levada polls seem to support Kurilla's suggestion that the expansion of Russian territory and conflictive relation with the West in one way or another triggered associations to Stalin's image as Victor and Imperial leader. 
In the years of the Putin and Medvedev presidencies, however, re-Stalinization initiatives have often been followed by corresponding de-Stalinization. Not only Stalin busts are erected, but also new monuments over Stalin's victims. Both Putin and Medvedev have routinely condemned Stalinist totalitarianism. ${ }^{96}$ In 2015, the Concept of State Policy to Perpetuate the Memory of the Victims of Political Repression was signed; prominent liberal Mikhail Fedotov led the work. ${ }^{97}$ This was not a fullfledged process of coming to terms with the past, however, but rather an initiative to commemorate the victims of repression without confronting the origins and agents of the terror. ${ }^{98}$ Another notable piece of policy running counter to the main line is the so-called Concept of a New Educational-Methodological Complex on National History, which is interesting because it was adopted on Putin's personal initiative in the midst of intensified authoritarianism. The concession to professional historians is clearly visible in this document, which pushes patriotism and military glory into the background and instead stresses Russia's status 'as a democratic law-based federal state' to which 'personal rights and freedoms are the highest values'.99

While some concessions target the liberal camp, others target the Orthodox Church. A case in point is the Russia -- My History project, a series of large-scale and interactive 'history parks' built in more than 15 locations across the country, designed to foster patriotic sentiments among the young. The Russian Orthodox Church was heavily involved in the project. Its values and interests shine through in the exhibitions, and miracles are seamlessly integrated with other explanatory factors. The religious line is not least visible with respect to the Soviet and Stalinist period. The upshot is that Stalinism is both condemned (for its atheism and anti-religious persecution) and rehabilitated (for the 1930s return to national values, industrialization, and strengthening of the state). ${ }^{100}$

In short, it seems incorrect to speak of a full-fledged rehabilitation of Stalinism under Putin's presidency. As Gjerde puts it, 'Stalin remains much more a problem than a resource in the search for a positive narrative. ${ }^{101}$ We can thus see how Russian history policy remains relatively flexible and able to reach out to professional historians and liberals even in the midst of a general authoritarian consolidation. The element of identity securitization, however, makes sure the historians do not step out of line: The state remains the final arbiter, at least when it comes to history for popular consumption. 


\section{Conclusions}

Official Russia, as well as independent elite actors, have been painting a picture of a Russian national identity under threat, legitimizing state involvement in the field of history and collective identity formation. On several occasions, security actors have been involved in defining and enforcing 'correct' versions of historical events, pushing professional historians aside. The co-existence of this phenomenon with repeated calls to counter perceived threats against Russian national identity, traditional values and cultural sovereignty shows how Russian history has been undergoing a process of securitization. In our material, securitizing actors typically present a version of reality where much harm has already befallen Russian national identity. Efforts to secure this identity, therefore, coexist alongside efforts to roll back harmful influence. Because the envisioned threats against Russian national identity are not merely looming, but already wreaking havoc, the securitization of national identity leads to active and explicit attempts to mend it and restore a purported 'natural' identity.

Since the turn of the millennium, the Kremlin's history policy has mainly promoted a statecentred and patriotic view of Russia's past, and it has done so mainly with respect to the Great Patriotic War. Celebrating military achievements and favouring unifying narratives, the primary purpose of this policy has been to rally the nation around a positive and heroic memory -- to encourage respect and love for the Russian state, historically and today. Publicly expressed notions about existential threats to Russian identity have enabled Kremlin's resort to heavy-handed tools in order to defend historical narratives against internal and external onslaught.

Securitization efforts have not targeted all salient historical topics, however. In particular, Russian history policy has been less heavy-handed when relating to the contentious issue of Stalinism. Here, the approach has included concessions to liberal as well as neo-Stalinist viewpoints. The historical Stalin appears divisive, and therefore poorly fit to build societal consensus. The approach to Stalinism shows that the Kremlin is not simply enforcing one final version of history, but rather attempts to manoeuvre in a polarized ideological landscape. While Russia has become more openly authoritarian since Putin started on his third term in office, liberal initiatives still carry an impact, as do the neoStalinist agenda. This does not imply that there is no structure or predictability to Russian history policy. 
It merely suggests that part of the policy, despite the ongoing securitization process, remains dynamic and negotiable.

Notes

${ }^{1}$ Moskovskaia oblastnaia Duma, 'Zasedanie ‘Otkrytoi Tribuny' Mosobldumy. Prepodavanie istorii kak faktor natsionalnoi bezopasnosti', no date $<$ mosoblduma.ru/folder/3945/item/60754> [accessed 21 June 2018].

${ }^{2}$ The Russian Institute for Strategic Studies is an official advisory think tank for the Presidential administration and other state organs in Russia, established by Presidential decree < riss.ru/about $>$ [accessed 7 December 2018].

${ }^{3}$ A.V. Evdokimov and S.V. Stakin, 'Ugrozy kul'turnoi bezopasnosti Rossii v kontekste prepodavania istorii v shkolakh', Rossiiskii institut strategicheskikh issledovanii (RISI), $2015<\mathrm{http} / /$ riss.ru/analitycs/11585/> [accessed 14 October 2018].

${ }^{4}$ Jardar Østbø, 'Securitizing 'Spiritual-Moral Values' in Russia', Post-Soviet Affairs, 33, 2017, pp. 212-13.

${ }^{5}$ Maria Mälksoo, 'Memory Must Be Defended.' Beyond the Politics of Mnemonical Security', Security Dialogue, 46, 2015, 3 pp. 221-37 (p. 227).

${ }^{6}$ Barry Buzan, Ole Wæver and Jaap de Wilde, Security. A New Framework for Analysis, Boulder, 1998, pp. 2324.

${ }^{7}$ On the issue of value pluralism, see Elena Chebankova, 'Competing Ideologies of Russia's Civil Society', Europe-Asia Studies, 67, 2015, 2, pp. 244-68 (p. 245). See also Oxana Shevel, 'Russian Nation-building from Yel'tsin to Medvedev: Ethnic, Civic or Purposefully Ambiguous?', Europe-Asia Studies, 63, 2011, 2, pp. 179202.

${ }^{8}$ Gulnaz Sharafutdinova. 'The Pussy Riot affair and Putin's démarche from sovereign democracy to sovereign morality,' Nationalities Papers, 42, 2014, pp. 615-23.

${ }^{9}$ See Buzan, Wæver and de Wilde, Security.

${ }^{10}$ See Edwin Bacon, Bettina Renz and Julian Cooper. Securitizing Russia. The Domestic Politics of Vladimir Putin. Manchester, 2007.

${ }^{11}$ Christopher S. Browning and Pertti Joenniemi 'Ontological Security, Self-Articulation and the Securitization of Identity', Cooperation and Conflict, 52, 2017, pp. 31-47, (p. 37).

${ }^{12}$ Karina Korostelina, 'War of textbooks: History education in Russia and Ukraine', Communist and PostCommunist Studies, 43, 2010, 2, pp. 129-137; Todd H. Nelson 'History as Ideology; the portrayal of Stalinism and the Great Patriotic War in contemorary Russain high school textbooks', Post-Soviet Affairs, 31, 2015, pp. 3765 .

${ }^{13}$ Julie Wilhelmsen, Russia's Securitization of Chechnya. How War Became Acceptable, London, 2017, p. 20-23.

${ }^{14}$ Nick Baron, 'History, Politics and Political Culture: Thoughts on the Role of Historiography in Contemporary Russia', Cromohs, 5, $2000<$ https://perma.cc/49KQ-9GP2> [accessed 12 December, 2018]..

${ }^{15}$ Thomas Sherlock, Historical Narratives in the Soviet Union and Post-Soviet Russia: Destroying the Settled Past, Creating an Uncertain Future, Houndmills, 2007.

${ }^{16}$ The expression 'historical masochism' was used by patriarch Kirill and quoted in Alexei Miller, 'A Year of Frustrated Hopes', Global Affairs, 18 December 2014.

${ }^{17}$ Quoted in Serguei Alex Oushakine, The Patriotism of Despair. Nation, War, and Loss in Russia, Ithaca, 2009, p. 104.

${ }^{18}$ Stephen M Norris, Blockbuster History in the New Russia. Movies, Memory, Patriotism, Bloomington, 2012.

${ }^{19}$ Quoted in Oushakine, The Patriotism of Despair, p. 111.

${ }^{20}$ G. F. Morozova, 'Degradatsia natsii -- mif ili realnost', Sotsiologicheskie issledovania, 21, 1994, pp. 22-30 (p. 22).

${ }^{21}$ Hans Bagger, 'The Study of History in Russia Duing the Post-Soviet Identity Crisis', Scando-Slavica, 53, 2007, pp. 109-25 (p. 119).

${ }^{22}$ Kathleen E. Smith, Mythmaking in the New Russia. Politics and Memory during the Yeltsin Era, Ithaca, 2002, p. 176.

${ }^{23}$ See Marlène Laruelle, In the Name of the Nation. Nationalism and Politics in Contemporary Russia,

Houndmills, 2009; Smith, Mythmaking in the New Russia.

${ }^{24}$ Ukaz Prezidenta Rossiiskoi Federatsii 'O merakh gosudarstvennoi podderzhki obshchestvennykh ob" edinenii, veduchshikh rabotu po voenno-patrioticheskomu vospitaniu molodezhi', Krasnaia zvezda, 22 June 1996.

${ }^{25}$ Norris, Blockbuster History in the New Russia. 
${ }^{26}$ Vladimir Putin, 'Address to the Federal Assembly', Kremlin.ru, 12 December 2012

$<$ en.kremlin.ru/events/president/news/17118> [accessed 7 December 2018]. Curiously, Yeltsin's advisor

Grigorii Satarov used the same metaphor seventeen years earlier to describe the same development. Smith, Mythmaking in the New Russia, p. 159.

${ }^{27}$ Galina Mikhaleva, 'Overcoming the Totalitarian Past', Russian Politics and Law, 48, 2010, pp. 35-45.

${ }^{28}$ Karina Korostelina, 'War of textbooks'.

${ }^{29}$ Mälksoo, 'Memory Must Be Defended', p. 227.

${ }^{30}$ Korostelina, 'War of textbooks'; Alexei Miller, 'Memory Control', Global Affairs, 17 June 2016; Anatoli Rapoport, 'Educating New Citizens. The Role of Patriotic Education in the Post-Soviet Countries', Educational Practice and Theory, 24, 2012, pp. 81-105.

${ }^{31}$ Mälksoo, 'Memory Must Be Defended', p. 222-23.

${ }^{32}$ Håvard Bækken, 'The Return to Patriotic Education in Post-Soviet Russia. How, When, and Why the Russian Military Engaged in Civilian Nation Building', Journal of Soviet and Post-Soviet Politics and Society, 5, 2019, pp. 123-58.

${ }^{33}$ Vladimir Shlapentokh, 'Perceptions of Foreign Threats to the Regime. From Lenin to Putin', Communist and Post-Communist Studies, 42, 2009, pp. 305-24; Østbø, 'Securitizing'.

${ }^{34}$ Alexander Rubtsov, 'The Growing Influence of History in Ideology', Raam op Rusland, 6 June 2017

$<$ raamoprusland.nl/dossiers/201-debat/geschiedschrijving-als-politiek-instrument/613-the-growing-influence-ofhistory-in-ideology> [accessed 6 December 2018].

${ }^{35}$ Putin, 'Address to the Federal Assembly', 12 December 2012.

${ }^{36}$ Vladimir Putin, 'Speech at Meeting with Public Representatives on Patriotic Education for Young People', Kremlin.ru, 12 September $2012<$ http://en.kremlin.ru/events/president/news/16470> [accessed 7 December 2018].

${ }^{37}$ Vladimir Putin, 'Reception to Mark National Unity Day', Kremlin.ru, 4 November 2013

$<$ http://en.kremlin.ru/events/president/news/19562> [accessed 7 December 2018].

${ }^{38}$ Irina Nagornykh and Viktor Khamraev, 'O roli totchnosti v istorii', Kommersant, 31 October 2016.

${ }^{39}$ Buzan et al., Security, p. 23.

${ }^{40}$ Browning and Joenniemi 'Ontological Security, p. 32.

41 'Russian National Security Strategy, December 2015 - Full-text Translation', Instituto Español de Estuidos Estratégicos $<w w w . i e e . e s /$ Galerias/fichero/OtrasPublicaciones/Internacional/2016/Russian-National-SecurityStrategy-31Dec2015.pdf> [accessed 7 December 2018].

${ }^{42}$ 'The Military Doctrine of the Russian Federation', The Embassy of the Russian Federation to the United Kingdom of Great Britain and Northern Ireland, 29 June $2015<$ https://rusemb.org.uk/press/2029> [accessed 7 December 2018].

${ }^{43}$ Nataliya Danilova, The Politics of War Commemoration in the UK and Russia, Houndmills, 2015, p.182.

${ }^{44}$ See for instance the selection of alleged 'civilian activity' (grazhdanskaia aktivnost) of the Russian Schoolchildren Movement (Rossiiskoe dvizhenie shkolnikov), which includes meeting with war veterans along with the 'Volunteeer of Victory' and searching for remains from WW2 <https://pдш.pф/activity/scope/3> [accessed 28 June 2018].

${ }^{45}$ See Markku Kangaspuro and Jussi Lassila, 'Naming the War and Framing the Nation in Russian Public Discussion', Canadian Slavonic Papers, 54, 2012, pp. 377-400. The consistent downplaying of events before operation Barbarossa has presumably contributed to the number of Russians believing the Molotov-Ribbentrop pact is a 'historical falsification' increasing from 9 to 17 per cent in 10 years. Levada, 'Obshchestvennoi Mnenie 2015', 2016.

${ }^{46}$ Quoted in Kristian Lundby Gjerde, 'The Use of History in Russia 2000-2011. The Kremlin and the Search for Consensus', East European Politics, 31, 2015, pp. 149-69 (p. 158).

${ }^{47}$ Quoted in Kangaspuro and Lassila, 'Naming the War', p. 378.

${ }^{48}$ E.g., Olga Kucherenko, 'That'll Teach'em to Love Their Motherland! Russian Youth Revisit the Battles of World War II', The Journal of Power Institutions in Post-Soviet Societies, 2015, 12, pp. 1-15.

${ }^{49}$ Alexei Miller, 'Russia. Power and History', Russian Politics and Law, 48, 2010, pp. 8-34 (p. 15).

${ }^{50}$ Laruelle, In the Name of the Nation.

51 'Putin Declares Patriotism Russia's Only National Idea', The Moscow Times, 4 February $2016<$ themoscowtimes.com/2016/02/04/putin-declares-patriotism-russias-only-national-idea-a51705> [accessed 16 September 2019].

${ }_{52}$ Here and below, references to the five-year plans of patriotic education point to the official state programs all bearing the name of Gosudarstvennaia programma patrioticheskogo vospitania grazhdan Rossiiskoi Federatsii, with different time period added. The first three state programs of patriotic education are publicly available (in Russian) in the Garant online database at $<\mathrm{http} / /$ base.garant.ru/1584972/>, $<\mathrm{http}: / /$ base.garant.ru/188373/> and $<$ http://base.garant.ru/199483/>, respectively. The fourth and current state program can be accessed on $<$ http://static.government.ru/media/files/8qqYUwwzHUxzVkH1jsKAErrx2dE4q0ws.pdf $>$. The Concept of 
Patriotic Education (Kontseptsia patrioticheskogo vospitaniia Rossiiskoi Federatsii) from 2003 is also available at Garant at $<$ http://base.garant.ru/6148105/> [all accessed 27 June 2018].

${ }^{53}$ Anna G. Sanina, 'Patriotism and Patriotic Education in Contemporary Russia', Sociological Research, 56, 2017, pp. 38-52;

${ }_{54}$ Françoise Daucé, 'Patriotic Unity and Ethnic Diversity at Odds: The Example of Tatar Organisations in Moscow', Europe-Asia Studies, 67, 2015, pp. 68-83.

${ }^{55}$ Kathy Rousselet, 'The Church in the Service of the Fatherland', Europe-Asia Studies, 67, 2015, pp. 49-67.

${ }^{56}$ J. Paul Goode, 'Everyday Patriotism and Ethnicity in Today's Russia', in Pål Kolstø and Helge Blakkisrud (eds.), Russia Before and After Crimea. Nationalism and Identity 2010-17, Edinburgh, 2018, pp. 258-81.

${ }^{57}$ For a discussion and more detailed analysis on the military and non-military purposes of the State Program of Patriotic Education, see Bækken, 'The Return to Patriotic Education'.

${ }^{58}$ Valerie Sperling 'Making the Public Patriotic. Militarism and Anti-Militarism in Russia', in Marléne Laruelle (ed.), Russian Nationalism and the National Reassertion of Russia, London, 2009, pp. 218-71; Laruelle, In the Name of the Nation; criticized in Danilova, The Politics of War Commemoration and Bækken, 'The Return to Patriotic Education'

${ }^{59}$ Kucherenko, 'That'll Teach'em to Love Their Motherland!'

${ }^{60}$ Bækken, 'The Return to Patriotic Education'.

${ }^{61}$ See Laruelle, In the Name of the Nation, p. 180

${ }^{62}$ Ivan Kurilla, 'The Russian Idea on the Small Screen. Staging National Identity on Russia's TV',

Demokratizatsiia, 22, 2014, pp. 313-33.

${ }^{63}$ Bækken, 'The Return to Patriotic Education'.

${ }^{64}$ Ibid.

${ }^{65}$ The full name being The Russian State Military Historical-Cultural Centre of the Government of the Russian Federation (Rosvoentsentr). Since the initiation of the current five-year plan, the coordination responsibility has been quietly moved to the Federal Agency of Youth Affairs (FADM), also known as Rosmolodezh', and to its subdivision The Russian Centre for Civilian and Patriotic Education of Children and Youth, Rospatriottsentr. ${ }^{66}$ Quoted in Mikhaleva, 'Overcoming the Totalitarian Past', p. 42.

${ }^{67}$ For a detailed discussion of the committee composition, see Pavel Polian, 'For Whom Did the Tsar Bell Toll?', Russian Social Science Review, 52, 2011, 3, pp. 55-70.

${ }^{68}$ 'Naryshkin Elected Chairman of Russian Historical Society', TASS, 21 June $2012<$ tass.ru/en/archive/677589> [accessed 27 June 2018].

${ }^{69}$ Rossiiskoe istoricheskoe obshchestvo, 'O Rossiiskom istoricheskom obshechestve' $<$ historyrussia.org/obobshchestve/o-nas.html> [accessed 27 June 2018].

70 'Russian National Security Strategy, December 2015'; 'Kontseptsia vneishnei politiki Rossiiskoi Federatsii (utverzhdena Prezidentom Rossiiskoi Federatsii V. V. Putinym 30 noiabria 2016 g.)’, Ministerstvo inostrannykh del Rossiiskoi Federatsii <www.mid.ru/foreign_policy/news/-

/asset_publisher/cKNonkJE02Bw/content/id/2542248> [accessed 7 December 2018].

${ }^{71}$ Niels Bo Poulsen, Skæbnekamp. Den tysk-sovjetiske krig 1941-1945, Copenhagen, 2016.

${ }^{72}$ E.g., Polian, 'For Whom Did the Tsar Bell Toll?'.

${ }^{73}$ Mälksoo, 'Memory Must Be Defended', p. 223

${ }^{74}$ Håvard Bækken, Law and Power in Russia. Making Sense of Quasi-Legal Practices, London, 2019.

${ }^{75}$ Mark Edele, 'Fighting Russia's History Wars. Vladimir Putin and the Codification of World War II', History \& Memory, 29, 2017, pp. 90-124.

${ }^{76}$ Miller, 'A Year of Frustrated Hopes'.

${ }^{77}$ The Panfilovtsy were twenty eight soldiers under Red Army General Panfilov who allegedly died while struggling heroically against Nazi forces outside Moscow in 1941, destroying eighteen Nazi tanks and forcing the enemy to retreat. The story of the Panfilovtsy has long been regarded as a legend by professional historians.

${ }^{78}$ The release date was later changed to November 2016. On the connection between the movie industry and state policies on history and patriotism, see Norris, Blockbuster History in the New Russia; 'Medinskii prizval Gosarkhiv otkazat'sa ot otsenok posle ostorii s Panfilovtsami', Lenta.ru, 30 July 2015

$<$ https://lenta.ru/news/2015/07/30/gosarch/> [accessed 7 December 2018].

79 'Nichego strashnogo v moem ukhode net', Kommersant, 16 March 2016.

${ }^{80}$ Ian Shenkman, 'Doktora! Minobrnauki lishil doktorskogo zvaniia istorika Kirilla Aleksandrova za dissertatsiu o generale Vlasove', Novaia Gazeta, 7 October 2017; 'Gulag Historian Yury Dmitriyev Hit With New Charges', The Moscow Times, 28 June 2018.

${ }^{81}$ Chebankova, 'Competing Ideologies'.

${ }^{82}$ Alexei Miller, 'The Labyrinths of Historical Policy', Global Affairs, 22 June 2011.

${ }^{83}$ Miller, 'A Year of Frustrated Hopes'.

${ }^{84}$ Gjerde, 'The Use of History in Russia 2000-2011', p. 150

${ }^{85}$ Ibid., p. 160 
${ }^{86}$ Ibid., p. 157.

${ }^{87}$ Boris Dubin, 'The Stalin Myth', Russian Politics and Law, 48, 2010, pp. 46-53; Vladimir Shlapentokh and Vera Bondartsova, 'Stalin in Russian Ideology and Public Opinion. Caught in a Conflict between Imperial and Liberal Elements', Russian History, 36, 2009, pp. 302-25; Anke Gizen, 'Raskolonaia pamyat'. Otrazhenie konflikta vokrug 'memorial'nogo tsentra Perm'-36' i rossiiskikh media', Zhurnal issledovanii sotsial'noi politiki, 13, 2015, pp. 363-76.

${ }^{88}$ Dubiun, 'The Stalin Myth', p. 48.

${ }^{89}$ Ibid.

${ }^{90}$ Putin quoted in Gjerde, 'The Use of History in Russia 2000-2011', p. 158.

${ }^{91}$ See e.g. Nina Khrushcheva, “'Rehabilitating' Stalin', World Policy Journal, 22, 2005, pp. 67-73.

${ }^{92}$ See Dina Khapaeva, 'Triumphant Memory of the Perpetrators: Putin's Politics of Re-Stalinization', Communist and Post-Communist Studies, 49, 2016, pp. 61-73.

${ }^{93}$ For more examples and discussion, see Khapaeva, 'Triumphant Memory'.

94 'Stalin i ego rol' v istorii strany', Levada-tsentr, 31 March $2015<$ https://www.levada.ru/2015/03/31/stalin-iego-rol-v-istorii-strany> [accessed 7 December 2018]; 'Stalin's Approval Rating Among Russians Hits Record High - Poll', The Moscow Times, 16 April 2019 <themoscowtimes.com/2019/04/16/stalins-approval-ratingamong-russians-hits-record-high-poll-a65245> [accessed 16 September 2019].

${ }^{95}$ Ivan Kurilla, 'The Return of Stalin.' Understanding the Surge of Historical Politics in Russia', Global Affairs, 11 October 2016.

${ }^{96}$ Maria Lipman, 'The Third Wave of Russian De-Stalinization', Foreign Policy, 16 December 2010; Thomas Sherlock, 'Confronting the Stalinist Past. The Politics of Memory in Russia', The Washington Quarterly, 31, 2011, pp. 93-109; Thomas Sherlock, 'Russian Politics and the Soviet Past: Reassessing Stalin and Stalinism under Vladimir Putin', Communist and Post-Communist Studies, 49, 2016, pp. $45-59$.

${ }^{97}$ Sherlock, 'Confronting the Stalinist Past', p. 105.

${ }^{98}$ Maria Mälksoo, 'In Search of a Modern Mnemonic Narrative of Communism. Russia's Mnemopolitical Mimesis During the Medvedev Presidency', Journal of Soviet and Post-Soviet Society, 1, 2015, pp. 317-40.

${ }^{99}$ Rabochaia gruppa po podgotovke kontseptsii novogo uchebno-metodicheskogo kompleksa po otechestvennoi istorii, 'Kontseptsia novogo uchebno-metodicheskogo kompleksa po otechestvennoi istorii', no date $<$ histrf.ru/uploads/media/artworks_object/0001/33/7cc368005497e45c317559844a44a7ca83b19d2d.pdf> [accessed 28 June 2018].

${ }^{100}$ See Marlene Laruelle, 'The Russian Orthodox Church's Conquest of the History Market', PONARS Eurasia, 7 June 2018 <perma.cc/MED6-JGWY> [accessed 7 December 2018].

${ }^{101}$ Gjerde, 'The Use of History in Russia 2000-2011', p. 158. 